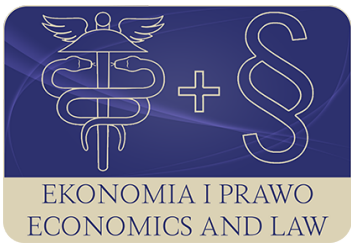

EKONOMIA I PRAWO. ECONOMICS AND LAW

Volume 19, Issue 3, September 2020

p-ISSN 1898-2255, e-ISSN 2392-1625

www.economicsandlaw.pl

EKONOMIA I PRAWO
ECONOMICS AND LAW

ORIGINAL ARTICLE

received 13.07.2019; revised 03.02.2020; accepted 30.09.2020

Citation: Kwarcińska, A. (2020). Reporting problems of corporate social responsibility. Ekonomia

iPrawo. Economics and Law, 19(3): 523-532.

doi:10.12775/EiP.2020.035.

\title{
Reporting problems of corporate social responsibility
}

\author{
AGNIESZKA KWARCIŃSKA \\ University of Szczecin, Institute of Management, Department of Human Capital Management, \\ ul. Cukrowa 8, 71-004 Szczecin, Poland \\ ๑agnieszka.kwarcinska@usz.edu.pl \\ (D) orcid.org/0000-0003-2766-1856
}

\begin{abstract}
Motivation: Respecting the principles of sustainable development and their application in the form of Corporate Social Responsibility strategy (CSR) is a real challenge for today's enterprises. This is not a simple and explicit task. Although, formulated general guidelines defining the framework for voluntary recognition of the rights of its stakeholders, each organization can shape mutual relations in an individual way. In turn, this specific character of implementation of the CSR strategy assumptions implies the difficulty of its transmis-

sion in the form of equivalent and comparable descriptions and indicators.

Aim: The aim of the article is primarily to identify the main problems associated with reporting of activities undertaken by enterprises under the implementation of the concept of corporate social responsibility and highlighting the importance of using unified reporting. The article presents both the theoretical approach to the concept of corporate social responsibility and the need for its description, as well as the perspective of practical recognition of individual aspects of CSR in social reports. It also underlines the importance of the Global Reporting Initiative (GRI), which is an attempt to introduce common reporting of sustainable development.

Results: In order to implement the objectives of this article, the literature on the subject, desk research in the form of social reports of chosen organizations, as well as GRI data and guidelines and also information of the Polish Ministry of Finance have been analyzed. The analysis has identified the main problems of CSR reporting and justified the appropriateness of applying a clear and unified message.
\end{abstract}

Keywords: corporate social responsibility; CSR reporting; GRI guidelines

JEL: M14 


\section{Introduction}

The realization of the aspirations of contemporary entities to respect the principles of sustainable development may be carried out in numerous ways. One of them is the implementation of the concept of corporate social responsibility (CSR). It covers ethical, economic, social and environmental aspects, which are harmonized with the premises of the concept of sustainable development. Its factual effect means the specific activities of the organization including different groups of stakeholders. Independent and individual selection of adequate initiatives remains a peculiar determinant of undertaking responsibility commitment. At the same time, it implies problems related to the reporting. This article first presents the sense of the CSR concept, the legitimacy of its implementation and the need for characterization. Then, attention was paid to the diversity of the description and the message of its application dimension. This allowed to indicate the resulting difficulties. Finally, the importance of using unified reporting was highlighted.

\section{Literature review}

The study of the literature on the subject of the concept of corporate social responsibility (CSR) first indicates on the constantly unflagging interest in this application response to the implementation of the concept of sustainable development. The authors of publications related to CSR consider, among others, problems of contemporary understanding (Dahlsrud, 2008, pp. 1-13; Kwarcińska, 2015, pp. 157-165; Sheehy, 2015, pp. 625-648) of this corporate moral responsibility towards a wide range of stakeholders, as well as they analyze practical problems concerning specific actions in specific CSR areas (Glavas, 2016, p. 796; Kwarcińska, 2018, pp. 223-230), reasons (Księżak, 2016, pp. 53-65) for their undertakings and issues of their descriptions (Hąbek \& Wolniak, 2016, pp. 399-420; Hys \& Hawrysz, 2012, pp. 1515-1524; Leitoniene \& Sapkauskiene, 2015, pp. 334-339).

\section{The CSR concept and the need to report it}

The real, constant evolution of the concept of corporate social responsibility is the basis for a reconsideration of its main message and understanding. The fundamental point of reference for this concept is invariably the ethical awareness of the organization and the recognition of its value for the implementation of economic intentions. Only then, as a result of this awareness, individual entities accept a moral responsibility for all intentions and actions that decide not only about their economic issues. Underlining in the definition of corporate social responsibility the impact of the organization on non-economic aspects, including their various stakeholders, has been formally recorded in the ISO 26000 standard. According to ISO (2010), social responsibility is the 'responsi- 
bility of an organization for the impacts of its decisions and activities on society and the environment through transparent and ethical behavior that:

- contributes to sustainable development, including the health and the welfare of society;

- takes into account the expectations of stakeholders;

- is in compliance with applicable law and consistent with international norms of behavior;

- is integrated throughout the organization and practised in its relationships'. Therefore, entities, which are aware of mutual economic-environmental-social interactions and are ethical, accept commitment to responsibility. This intangible sense of duty of enterprises is not connected with necessity; it does not result from formal requirements and is not an ultimatum of running a business. Therefore, among others, in the determination of social responsibility, the voluntary aspect often appears. According to European Commission (2001), CSR is a 'concept whereby companies integrate social and environmental concerns in their business operations and in their interaction with their stakeholders on a voluntary basis'. The voluntary nature means a certain freedom of decision for each organization in this respect and at the same time refers to the fundamental meaning of intangible ethical values. Meanwhile, in the literature on the subject, there are also CSR explanations through the prism of real, measurable benefits for both organization and society. Paliwoda-Matiolańska (2012, p. 177) stated that CSR is 'a process of managing relations with stakeholders of the company, which through responding to identifiable expectations, contributes to the growth of the company's competitiveness providing it with stability and lasting development and at the same time establishes favourable conditions for social and economic development creating both social and economic value'. Thus, the considerations on corporate social responsibility from the level of consciousness, the way of thinking and the sense of the need to accept the responsibility are heading towards general economic and social benefits. Benefits stemming from such commitments are primarily related to respecting and regarding the interests of different parties from the close and far surroundings of the enterprises. In practice, this means the mutual formation of relationships with entities that influences on the decisions and activities of the organization, as well as on those, which the enterprises interact with. The respect for mutual reasons translates into specific actions of enterprises in respect of their stakeholders. In turn, taking all initiatives is subject to the criteria of a relatively significant freedom in selecting stakeholder significance, as well as selecting the type of activities for them. Therefore, it does not necessarily mean a comprehensive approach to all stakeholders and to take clear and identical activities. The reasons of the organizations, which decide to pay attention to their stakeholders, are important elements in this process. Among reasons, it can also be seen a high degree of their differentiation. There are the most general ones, such as ethical awareness or the desire to improve the image of the organization and those aimed at improving relations with each of the stakeholders. This 
translates into multidimensionality and diversity of specific activities, and thus the reporting of organizations in this field. Corporates undertaking social responsibility communicate their commitment to all interested parties by presenting such information most often in the form of social reports.

\section{The variety of social reports}

Reporting in the scope of non-financial activities of enterprises is differently understood and in practice, adopts inconsistent terms ranging from additional statements and reports on non-financial data, through sustainability reports, social impact reports, social responsibility reports, to integrated reports. It seems that the most general and binding name is the definition of social reports. The essence is their content. Most often, they communicate all activities of the organization including the social, ethical and environmental areas, based on the specified stakeholders.

Analysis of selected social reports of various organizations available on websites: of CSRinfo (2019) and the reports submitted within several editions of the Social Reports competition in the years 2014-2017, among other things, made it possible to note that they are very broad and significantly different in form and content. The reasons for this are primarily related to the relatively high degree of voluntariness and freedom, as well as the lack of unambiguous and specific formal requirements, as well as legal obligations regarding the form of such a report in relation to all organizations. Even entities that since 2017, in Poland have been legally obliged to report non-financial information in accordance with the amendment to the Accounting Act (2016), can freely choose the standard of report preparation using only general records indicating the disclosure of data concerning at least the following issues: environmental, social and employee issues, respect for human rights and counteracting corruption and bribery, including (Dadacz, 2019):

- a concise description of the business model of the entity;

- key, non-financial performance indicators related to the entity's operations;

- description of policies used by the entity in relation to social and employment issues, the natural environment, respect for human rights and counteracting corruption and bribery, as well as description of the results of applying these policies;

- description of due diligence procedures - if the entity uses them under the aforementioned policies;

- description of significant risks related to the entity's activities in relation to environmental, social and employee issues, respect for human rights and counteracting corruption and bribery, including risks related to the entity's products or its relations with the external environment, including contractors, as well as description managing these risks.

The analyzed reports in their content in a different scope and with different intensity refer to the goals, ambitions of the organization and their im- 
plementation. They describe the products; their quality and striving for their improvement taking into account the needs of customers, but also with a view to the protection of the natural environment. They present relationships with employees, suppliers, contractors and commitment to the local community. Thus, they present non-financial aspects of functioning through the prism of ethical and responsible recognition of the reasons of various stakeholders. They refer to the main values to the corporates, such as trust, honesty and respect, especially at the level of formulating visions, strategies or partial policies. At the same time, indicated postulates and obligations regarding the application of the principles of responsible business activity often refer to international guidelines and standards.

In the majority of reports, employees, customers, contractors, suppliers, local community and natural environment are identified as the main stakeholders. Presentation of their recognition and emphasizing responsibility towards them is based on the presentation of mutual relations as well as specific actions taken towards them. They are so-called good practices that allow to identify specific areas and ways of corporate responsible impact. Their recognition depends to a large extent, on the type of activity of the entity, its experience and main problems. This means that if a company operates in a sector with a significant threat to human health and life, it undertakes initiatives that promote solutions and proposals in the area of improving occupational safety relatively more frequently and intensively. In turn, if the entity is aware of its intense interfering with the state of the natural environment, it focuses attention on efforts to minimize damage, as well as preventive and corrective actions in relation to natural environment. Examples of specific activities towards major stakeholders are presented in table 1 .

The analysis of the information presented in table 1 allows to observe, among others, a significant diversification of activities with regard to different stakeholders. This is due to the lack of requirements regarding both taking actions towards specific entities and the type of initiatives. This underlines the importance of the principle of voluntary responsibility commitment and the existence of a high degree of freedom in adjusting commitment. Entrepreneurs themselves identify the most important stakeholders and individually decide on the strength of impact and shaping mutual relations.

This voluntariness and freedom constitute the basic problems in the description and comparison of social responsibility issues. In addition, social reports are often the business card of an organization, and if it acts responsibly, it reveals these positive aspects of its functioning and focuses solely on them. Meanwhile, an objective picture should also include the ranges, in which a specific entity does not take up activities or those, in which it is possible to indicate incorrect, inadequate, insufficient actions. It is also important to pay attention to the desirability of developing a report and the need to maintain its transparency. Excessive information in reports or their inadequacy in relation 
to the target function and information needs of the recipients make them too large and non-transparent.

The answer to the problems of preparing social reports are, among others, the guidelines of the Global Reporting Initiative (GRI) organization, which application was also observed in the reports analyzed for the purposes of this article.

\section{The GRI initiative as a way to report corporate social responsibility}

The international organization GRI has been operating since 1997 and since then, based on constant consultations and cooperation with many organizations and experts, it has been continuously improving reporting on sustainable development. Its main goal is 'to create international reporting standards voluntarily used in reporting in the economic, environmental and social areas' (FOB, 2008). In 2000, the first version of the GRI-Gl guidelines was published. Their subsequent modifications in 2002 (GRI-G2), 2006 (GRI-G3), 2011 (GRI update: G3.1), 2013 (GRI: G4) led to the preparation in 2016 of a consolidated set of GRI standards referred to as GRI standards. This set of instruments consists mainly of three universal standards named as (FOB, 2016):

- basic information (GRI 101);

- profile indicators (GRI 102);

- approach to management (GRI 103).

It also contains 33 topic - specific standards, defined as series:

- economic (GRI 200) - 6 standards;

- environmental (GRI 300) - 8 standards;

- social (GRI 400) - 19 standards.

The guidelines are prepared for the needs of various organizations regardless of the nature of their activities and size. Their universality also applies to the freedom to use only selected standards or even only parts of them. The structure of the social report developed according to the GRI guidelines is transparent and structured. It allows to include both strategic and very detailed activities, while creating opportunities to take into account the positive and negative actions of the organization. According to the guidelines, information provided through the report should serve internal and external stakeholders. Therefore, on their basis, stakeholders can form opinions about the organization's contribution to sustainable development and make informed decisions. The basic principle of reporting is focusing on relevant aspects, i.e. those that reflect the significant impact of the organization on the economy, the environment and society, or that have a significant impact on the assessments and decisions of stakeholders (GRI, 2018a, p. 3; 2018b, p. 11). This rule seems to be indispensable because in a complete approach to standards, the report becomes a very extensive study. 
In nearly twenty years, the application of GRI principles and guidelines has become a useful and widespread tool for non-financial reporting. According to the GRI (2019) information, over 13.5 thousands organizations from around the world have prepared approximately 53 thousands reports so far, of which almost 32 thousands have been based on the GRI guidelines.

The GRI guidelines are also used by Polish entities. The analysis of the register of social reports shows that in $2009,50 \%$ of reports were prepared according to the GRI guidelines, and in 2018, it was already 75\%. Detailed information on this subject is presented in table 2 .

It should be emphasized that in Poland, the reporting of non-financial information was completely non-obligatory until 2016, since 2017 (Act amending the Accounting Act, 2016) the entities of public interest have been obliged to reporting while maintaining the voluntary principles used to prepare declarations. In the materials presenting the reporting of non-financial information in Poland in 2017 (Ministry of Finance, 2019), nearly 250 such entities were identified; however, the analysis covered 123 reports. 40\% (Dadacz, 2019) of them were prepared using GRI G4 standards, 22\% included the Non-Financial Information Standard (SIN), 20\% were based on their own rules, $14 \%$ were based on GRI Standards and 4\% were developed according to other guidelines. Therefore, it can be noticed that the GRI guidelines have been used extensively. Their value is supported by both universality and many years of development by various groups of specialists and consultants. Nevertheless, it should be noted that at least in Poland the reporting of non-financial aspects is the domain of large entities. Therefore, the issue to use of GRI guidelines by medium and small organizations remains open.

\section{Conclusion}

The actual activities of each organization determine its awareness of responsibility and its commitment to the implementation of the concept of sustainable development. However, the significant variety of initiatives undertaken with regard to various stakeholders and with uneven intensity implies problems of recognition and reporting. It is difficult to compare information on the scope of entities' responsibility, determine its degree and distinguish irresponsible activities. Probably more often positive aspects of the functioning of each organization are described and disclosed. On the other hand, due to the necessity undesired or marginalized issues of the corporates are verbalized. Among other things, it is justified to try to standardize non-financial reporting. Even if they are not completely comparable information and will not cover all ranges, each report is a specific set of so-called good practices that can serve as a benchmark for new activities of other organizations. Reporting, even in a narrow scope, inspires to take initiatives in other areas and leads to better target of management activities. Above all, however, it is a valuable source of data for current and po- 
tential stakeholders. They ultimately expect such information and on the basis of which they make an assessment and make decisions.

\section{References}

Anam, L. (2019). Raportowanie niefinansowe w Polsce 2019: bilans otwarcia. Retrieved 23.04.2019 from http://www.csrinfo.org.

CSRinfo. (2019). Największa baza raportów niefinansowych $w$ Polsce. Retrieved 15.04.2019 from http://www.rejestrraportow.pl.

Dadacz, J. (2019). Raportowanie niefinansowe w Polsce: konferencja Ministerstwa Finansów. Retrieved 15.04.2019 from https://www.gov.pl.

Dahlsrud, A. (2008). How corporate social responsibility is defined: an analysis of 37 definitions. Corporate Social Responsibility and Environmental Management, 15(1). doi:10.1002/csr.132.

Energa. (2017). Nasza odpowiedzialność. Retrieved 14.02.2019 from http:// raportyspoleczne.pl.

European Commission. (2001). Green paper: promoting a European framework for corporate social responsibility. Retrieved 03.05.2019 from https://ec.europa. eu.

FOB. (2008). Global Reporting Initiative: czyli trochę o raportowaniu spotecznym. Retrieved 10.02.2019 from http://odpowiedzialnybiznes.pl.

FOB. (2016). Ukazaty się nowe standardy raportowania GRI. Retrieved 23.04.2019 from http://odpowiedzialnybiznes.pl.

Glavas, A. (2016). Corporate social responsibility and employee engagement: enabling employees to employ more of their whole selves at work. Frontiers in Psychology, 7. doi:10.3389/fpsyg.2016.00796.

Górażdże Heidelberg Cement Group. (2016-2017). Raport zrównoważonego rozwoju Grupy Górażdże. Retrieved 14.02.2019 from http://raportyspoleczne. pl.

GRI. (2018a). GRI 101: foundation. Retrieved 15.04.2019 from https://www. globalreporting.org.

GRI. (2018b). GRI standards glossary 2018. Retrieved 15.04.2019 from https:// www.globalreporting.org.

GRI. (2019). Sustainability disclosure database. Retrieved 23.04.2019 from http://database.globalreporting.org.

Hąbek, P., \& Wolniak, R. (2016). Assessing the quality of corporate social responsibility reports: the case of reporting practices in selected European Union member states. Quality \& Quantity, 50(1). doi:10.1007/s11135-014-0155-z.

Hys, K., \& Hawrysz, L. (2012). Corporate social responsibility reporting. China-USA Business Review, 11(1). doi:10.17265/1537-1514/2012.11.009.

Idea Bank. (2017). Raport odpowiedzialnego biznesu Idea Bank 2017. Retrieved 14.02.2019 from http://raportyspoleczne.pl.

ISO. (2010). ISO 26000:2010 guidance on social responsibility. Retrieved 02.05.2019 from https://www.iso.org. 
Księżak, P. (2016). The benefits from CSR for a company and society. Journal of Corporate Responsibility and Leadership, 3(4). doi:10.12775/jcrl.2016.023.

Kwarcińska, A. (2015). Corporate social responsibility jako zobowiązanie moralne biznesu. Wspótczesne Problemy Ekonomiczne, 10.

Kwarcińska, A. (2018) Social responsibility of enterprises towards employees: theoretical and practical aspects. European Journal of Service Management, 4.

Leitoniene, S., \& Sapkauskiene, A. (2015). Quality of corporate social responsibility information. Procedia: Social and Behavioral Sciences, 213. doi:10.1016/j. sbspro.2015.11.547.

Ministry of Finance. (2019). Raportowanie rozszerzonych informacji niefinansowych za 2017 rok. Retrieved 23.04.2019 from https://www.gov.pl.

Mostostal Warszawa. (2017). Oświadczenie na temat informacji niefinansowych Mostostal Warszawa SA. Retrieved 14.02.2019 from http://raportyspoleczne.pl.

Paliwoda-Matiolańska, A. (2012). Social responsibility in business in theory and practice. Marketing of Scientific and Research Organizations, 223.

Provident. (2016-2017). O etyce i zaangażowaniu. Raport spotecznej odpowiedzialności biznesu Provident Polska. Retrieved 14.02.2019 from http://raportyspoleczne.pl.

Sheehy, B. (2015). Defining CSR: problems and solutions. Journal of Business Ethics, 131(3). doi:10.1007/s10551-014-2281-x.

Ustawa z dnia 15 grudnia 2016 r. o zmianie ustawy o rachunkowości [Act of 15 December 2016 amending the Accounting Act] (Dz.U. 2017 poz. 61) (Poland).

Velux. (2016-2017). Odpowiedzialność: zobacz to czego nie widać od razu: raport spotecznej odpowiedzialności. Retrieved 14.02.2019 from http://raportyspoleczne.pl.

\section{Acknowledgements}

Author contributions: author has given an approval to the final version of the article.

Funding: this research was undertaken as part of the Minister of Science and Higher Education program Regional excellence initiative and was fully funded by project (001/ RID/2018/19).

Note: the results of this study were presented at 8th International Scientific Conference: Contemporary Economic Problems 'Social-economic problems in the era of globalization: theory and practice' (May, 22, 2019, Torun, Poland). 


\section{Appendix}

\section{Table 1.}

\section{Examples of actions towards stakeholders}

\begin{tabular}{lc}
\hline \multicolumn{1}{c}{ Stakeholders } & Examples of initiatives \\
employees & $\begin{array}{c}\text { programs for school and academic students, onboarding programs, codes of conduct, } \\
\text { organizing a health and safety week, health and safety awareness contests, medical care } \\
\text { packages, sports cards for employees and their families, workshops, satisfaction surveys }\end{array}$ \\
\hline customers & $\begin{array}{r}\text { surveys describing the level of satisfaction, direct meetings, reference letters from custom- } \\
\text { ers, customer service standards, internet services }\end{array}$ \\
\hline contractors, suppliers & conferences, participation in fairs, opinion polls, audits, codes of standards \\
\hline local society & $\begin{array}{c}\text { presence in social media, sports support, workshops for children, sponsorship, organiza- } \\
\text { tion of competitions, charity events, meetings with the community, employee volunteer- } \\
\text { ing, open days }\end{array}$ \\
\hline & $\begin{array}{c}\text { awareness training, car exchange, implementation of eco-innovations, exchange of tra- } \\
\text { ditional lighting, reduction of paper consumption, promotion of bicycle transport, use } \\
\text { of alternative fuels }\end{array}$ \\
\hline
\end{tabular}

Source: Own preparation based on Energa (2017, p. 44, 61, 83, 126, 131, 136, 145, 146, 171), Górażdże Heidelberg Cement Group (2016-2017, p. 18, 19, 27, 30, 49, 57, 72, 75), Idea Bank (2017, p. 36, 40, 43, 52), Mostostal Warszawa (2017, p. 18, 19, 21, 26, 31, 32, 36, 40, 61), Provident (2016-2017, p. 39, 82), Velux (2016-2017, p. 4, 27, 28, 37, 50).

Table 2.

\section{Polish social reports}

\begin{tabular}{|c|c|c|c|c|c|c|c|c|c|c|}
\hline Specification & 2009 & 2010 & 2011 & 2012 & 2013 & 2014 & 2015 & 2016 & 2017 & 2018 \\
\hline $\begin{array}{l}\text { number of non-financial reports } \\
\text { submitted to the register of reports } \\
\text { published on the website CSRinfo } \\
\text { (2019) }\end{array}$ & 14 & 25 & 34 & 37 & 48 & 40 & 55 & 43 & 52 & 72 \\
\hline $\begin{array}{l}\text { including the number of GRI } \\
\text { reports }\end{array}$ & 7 & 10 & 16 & 25 & 37 & 33 & 45 & 33 & 36 & 54 \\
\hline the percentage of GRI reports & 50 & 40 & 47 & 68 & 77 & 83 & 82 & 77 & 69 & 75 \\
\hline
\end{tabular}

Source: Own preparation based on Anam (2019). 